\begin{tabular}{|l|c|c|c|c|}
\hline $\begin{array}{l}\text { Cuadernos de Investigación Geográfica } \\
\text { Geographical Research Letters }\end{array}$ & 2019 & N $^{\circ} 45(2)$ & pp. 469-486 & eISSN 1697-9540 \\
\hline
\end{tabular}

\title{
EVOLUTION OF ARGOMA SHRUBLAND (ULEX GALLII PLANCH.) AFTER CLEARING AND BURNING TREATMENTS IN SIERRA DE ARALAR AND BELATE (NAVARRA)
}

\author{
D. GÓMEZ1*, A.J. AGUIRRE ${ }^{2}$, X. LIZAUR ${ }^{1}$, M. LORDA ${ }^{3}$, J.L. REMÓN ${ }^{4}$ \\ ${ }^{1}$ Instituto Pirenaico de Ecología. Avda. Ntra. Sra. de la Victoria, 16, 22700 Jaca, Huesca, Spain. \\ ${ }^{2}$ Faculty of Agricultural and Animal Sciences, University of Cuenca, Ecuador. \\ ${ }^{3}$ C.I. Agroforestal, Avda. Villava, 55, 31015 Pamplona-Iruña, Navarra, Spain. \\ ${ }^{4}$ Consultor Ambiental y Pastos, Pamplona-Iruña, Spain.
}

\begin{abstract}
Shrub encroachment is considered one of the greatest threats in the conservation of pastures, especially in abandoned territories and territories with low stocking density. However, in the Navarra Pyrenees and Basque mountains, with a high stocking density maintained during the last decades, the expansion of argoma shrubland (Ulex gallii), shows that grazing is not enough for its control and requires evaluating measures of clearing. To evaluate the efficiency of the burning and the mechanical clearing (with two treatments: at ground level and $10 \mathrm{~cm}$ above ground) in the control of the shrub, these treatments were applied in different plots of encroached grasslands in two pastoral territories (Sierra de Aralar and Belate). After the burning and clearing, the evolution of the shrub was compared in the cleared plots closed to grazing and in their replicas open to it. The results showed differences between the different treatments in both territories that may be related to the initial coverage of the shrubland. In general, burning was less effective in controlling shrubland and allowed a greater resprout than mechanical clearing. No significant differences were found between the two types of mechanical clearing (at ground level and at $10 \mathrm{~cm}$ above ground). Finally, grazing caused a delay in the recovery of the shrub in all cases, but it was not able to eliminate the shrubs completely. From the field observations, the opinions of the farmers and the results of similar experiences, some measures for grassland management were collected and discussed to correct or complement the clearing treatments in order to increase their efficiency.
\end{abstract}

Evolución del matorral de argoma (Ulex gallii Planch.) tras tratamientos de desbroce y quema en la Sierra de Aralar y en Belate (Navarra)

RESUMEN. La matorralización se considera una de las mayores amenazas en la conservación de pastos, sobre todo en los territorios abandonados o con escasa carga ganadera. Sin embargo, en el Pirineo navarro y los Montes Vascos, la expansión del argomal (Ulex gallii), a pesar del mantenimiento durante las 
últimas décadas de una alta carga ganadera, cuestiona dicha causa, muestra que el pastoreo es insuficiente para su control y aconseja evaluar medidas de desbroce. Para comparar la eficacia en el control del matorral de la quema y el desbroce mecánico (con dos tratamientos: a ras de suelo y a $10 \mathrm{~cm}$ sobre el mismo), se aplicaron dichos tratamientos en distintas parcelas con pasto matorralizado de dos territorios pastorales (Sierra de Aralar y Belate). Tras la quema y el desbroce, se comparó la evolución del matorral en las parcelas desbrozadas cerradas al pastoreo y en sus réplicas abiertas al mismo. Los resultados muestran diferencias entre los distintos tratamientos en ambos territorios que pueden estar relacionadas con la cobertura inicial del matorral. En general, la quema ha supuesto un freno menor a la matorralización y ha permitido un rebrote mayor que el desbroce mecánico. No hay diferencias significativas en el rebrote del matorral entre los dos tipos de desbroce mecánico (a ras de suelo y a $10 \mathrm{~cm}$ ). Por último, el pastoreo ha ocasionado un retraso en la recuperación del matorral en todos los casos, si bien no ha conseguido su eliminación. A partir de las observaciones realizadas en el terreno, las opiniones de los ganaderos y resultados de experiencias similares, se recogen y discuten algunas medidas para corregir o complementar los tratamientos de desbroce que pueden servir para aumentar su eficacia.

Key words: shrub encroachment, grassland management, clearing, conservation.

Palabras clave: matorralización, mejora de pastos, desbroce, conservación.

Received: 17 September 2018 Accepted: 20 November 2018

*Corresponding author: Daniel Gómez García, Instituto Pirenaico de Ecología, Consejo Superior de Investigaciones Científicas (IPE-CSIC), Avda. Ntra. Sra. de la Victoria, 16, 22700 Jaca, Huesca, Spain. E-mail address: dgomez@ipe.csic.es

\section{Introduction}

Shrub encroachment refers to the process of shrub expansion in different plant communities, affecting their surface occupation, density, cover and biomass, with special damage to the herbaceous plants (Schlesinger et al., 1990). This process has been observed for decades (Allred, 1949) in very different territories, climates, environmental conditions and histories of use (Van Vegten, 1984; Hobbs and Mooney, 1986; Burrows et al., 1990; Elridge et al., 2011), and is now recognized as a "global process" (Liu et al., 2013). The causes to which it is attributed are also heterogeneous and include variations in the concentration of atmospheric $\mathrm{CO}_{2}$ (Van Auken, 2000; Archer, 2009), global warming (Knapp et al., 2008), cessation or change of frequency in the fire rate (Scholes and Archer, 1997), overgrazing (Coetzee et al., 2008) and changes in land use, including abandonment (Schlesinger et al., 1990; Archer et al., 1995; Van Auken, 2000). Shrub encroachment is identified as one of the greatest threats in the conservation of mesophitic grasslands (Briggs et al., 2005). In southern 
Europe, concern for this phenomenon and its link with rural depopulation and the abandonment of traditional practices has been more recent (Pinto-Correia, 1993; Maestre et al., 2009; Lasanta et al., 2009).

In the Navarrese mountains of the Sierra de Aralar and Belate, grazing is ancestral and nowadays there is still a very active livestock with a stable or even increasing stocking density and an intense use of pastures (Remón Aldabe, 2008). In these circumstances, the increase in shrub cover is a major concern for farmers (Alberdi Collantes, 2003), as in other mountains in nearby territories (FernándezGiménez and Fillat, 2012). This concern exerts increasing pressure to the managers in demand of action measures. The use of pastoral fire, a common practice until two decades ago to stop undesirable shrubs and ferns spread, is currently very restrictively regulated (BON, 2006). It should be noted that the pastures of this territory, except for very small enclaves with abrupt topography and very shallow soils, constitute "secondary communities" maintained by ancestral grazing in the domain of the beech forest. Therefore, the lignification of the vegetation is interpreted, especially in the framework of the legal forms of protection, as an ecological process that traverses the plant succession towards the "climax" forest expected in a large part of the territory (Aseginolaza et al., 1988).

From an anthropocentric perspective, lignification of vegetation shows advantages and disadvantages (Maestre et al., 2003; Lasanta et al., 2009, 2011). Among the first, now evaluated as "ecosystem services" (Hochtl et al., 2005), the protection of the soil from erosion or an increase in $\mathrm{CO}_{2}$ fixation (Maestre et al., 2003) may be mentioned. In the opposite direction and focused on grazing, shrub encroachment produces a reduction in rangeland area, cover and quality of pasture (Ward, 1990; Calvo et al., 2005; Zarovali et al., 2007) that hampers the movement of livestock and their access to certain parts of the territory. In addition, vegetation thickening (in short, the increase of lignin) is supposed to increase the retention of water resources and the risk of fires (Lasanta et al., 2011) due to its greater biomass. Finally, shrub encroachment can cause a decrease in biodiversity and affects habitats of high conservation interest (Dolman and Sutherland, 1992). In the Atlantic regions, the detraction of water resources and the risk of fire suppose less concern in the management of the territory. On the contrary, the maintenance of grazing is essential for the conservation of the landscape and pastures that, without herbivory, would be relegated to enclaves where the topography and scarcity of soil prevent forest development. In addition, the current socio-economic framework of the territory ensures the continuity of livestock with high demand for grasslands and, consequently, the pressure of farmers demanding action measures.

The efficiency of the "fight against the shrub" treatments (consisting of plant mortality or brake to its young sprouts, together with the regeneration of the herbaceous pastures) (Redhead et al., 2012) depends on the shrub phenological and morphological characteristics (Scholes and Archer, 1997; Verdú, 2000; Maestre et al., 2009) which description requires a detailed spatial and temporal analysis of the plant. Moreover, the evaluation of advantages and disadvantages related 
to the management should also be considered in the choice of the treatment. The response of the vegetation after different treatments of clearing has been studied in environments with Atlantic climate and different dominant shrubs, such as Calluna vulgaris (L.) Hull, Cistus spp., Erica arborea L. (Calvo et al., 2005) and in shrubs of argoma (Ulex gallii Planch.), mainly to test their effectiveness in fire prevention (Fernández Filgueira et al., 2013).

After evaluating different treatments, several authors have advocated the mechanical clearing to control the negative effects of revegetation in territories with abandonment (Lasanta et al., 2015, 2016). However, the practice of mechanical clearing is expensive in material and workforce and is difficult in areas far away from access roads. The use of fire by controlled burning also depends, for security reasons, on accessibility, although its practice is secular, simpler in cost and personnel, and can be applied to large areas with homogeneous shrub cover (Métailié, 1981). The impact of fire on soils is difficult to evaluate, as it depends on the characteristics of the soil, the fire (intensity and severity) and the vegetation itself (Armas-Herrera et al., 2016; Badía et al., 2017; Alcañiz et al., 2018). In some cases a great risk of erosion has been reported, as in Nadal-Romero et al. (2018) who showed that soil loss was three times greater in the burnt plots than in the control plots.

In this framework and on request of the Department of the Environment of the Government of Navarra, several shrub removal treatments were carried out in the pastoral areas of Belate and Sierra de Aralar, with the goal of collecting suggestions for land management. Specifically, the aim was to verify, through field monitoring during successive years, the effectiveness of several treatments in shrub control, the improvement of pastures, the avoidance of erosion and the preservation of plant diversity and plant species with high conservation interest (Lizaur and Gómez García, 2007, 2008; Gómez García et al., 2011). In this work we evaluated the evolution of argoma shrub (Ulex gallii Planch.) after burning and clearing treatments and analyzed the effect of grazing on this evolution.

\section{The study area}

The study was developed in two pastoral territories of the Sierra de Aralar and Belate (Figs. 1 and 2). In the Sierra de Aralar, limestone and sandy materials, marls and sandstones predominate. Many of these limestones have a karstic morphology, where dolines, lapiaces, uvalas and chasms stand out. Despite the predominance of these substrates and due to the deep washing of the soil, the soils are mostly acidic -Eutrochrept associated to Lithic Xerorthent with inclusions of Lithic Xerorthent and Ultic Hapludalf (Iñiguez et al., 1990) - with top horizon pH in the study plots between 4.8 and 5.2. In Belate, siliceous rocks predominate, rich in shales, schists and quartzites that give rise to more acid soils -Xerorthent or Lithic Udorthent and Entic Haplumbrept (Iñiguez et al., 1990)- with top horizon $\mathrm{pH}$ in the study area around 4.3. 


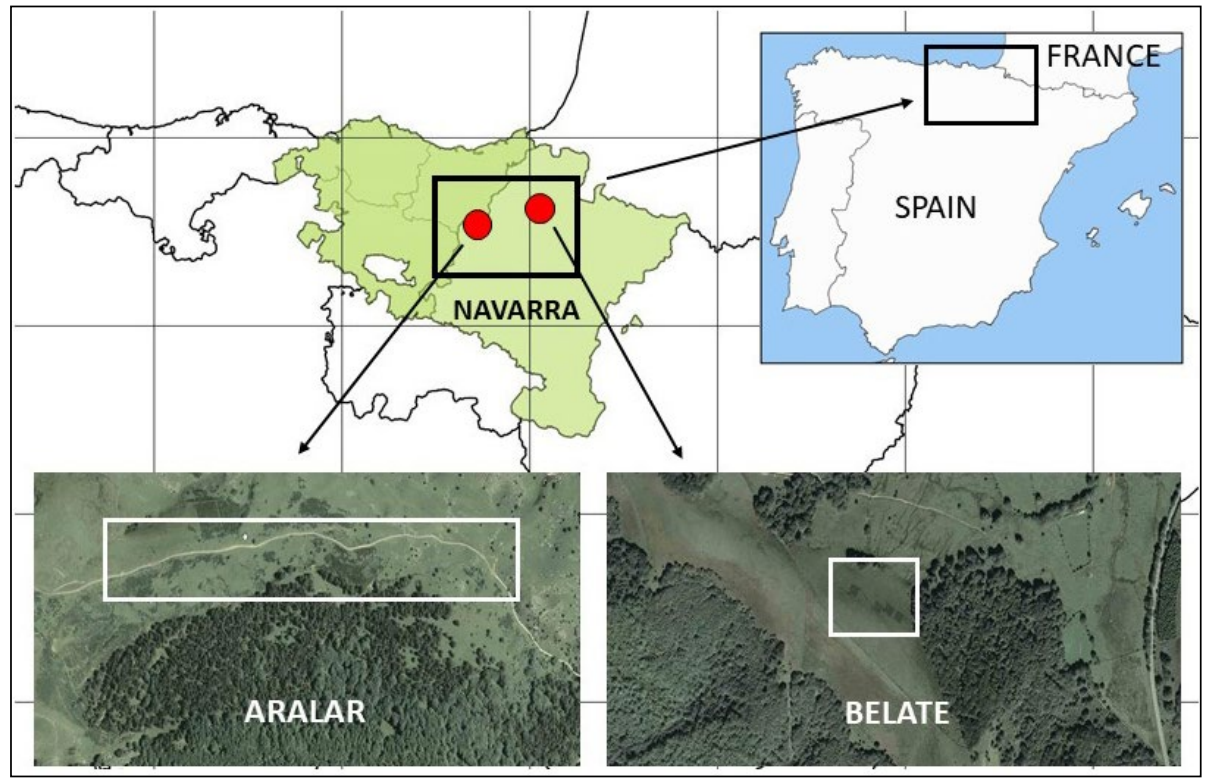

Figure 1. Location of the two study sites (Sierra de Aralar and Belate) in the Pyrenees of Navarra.
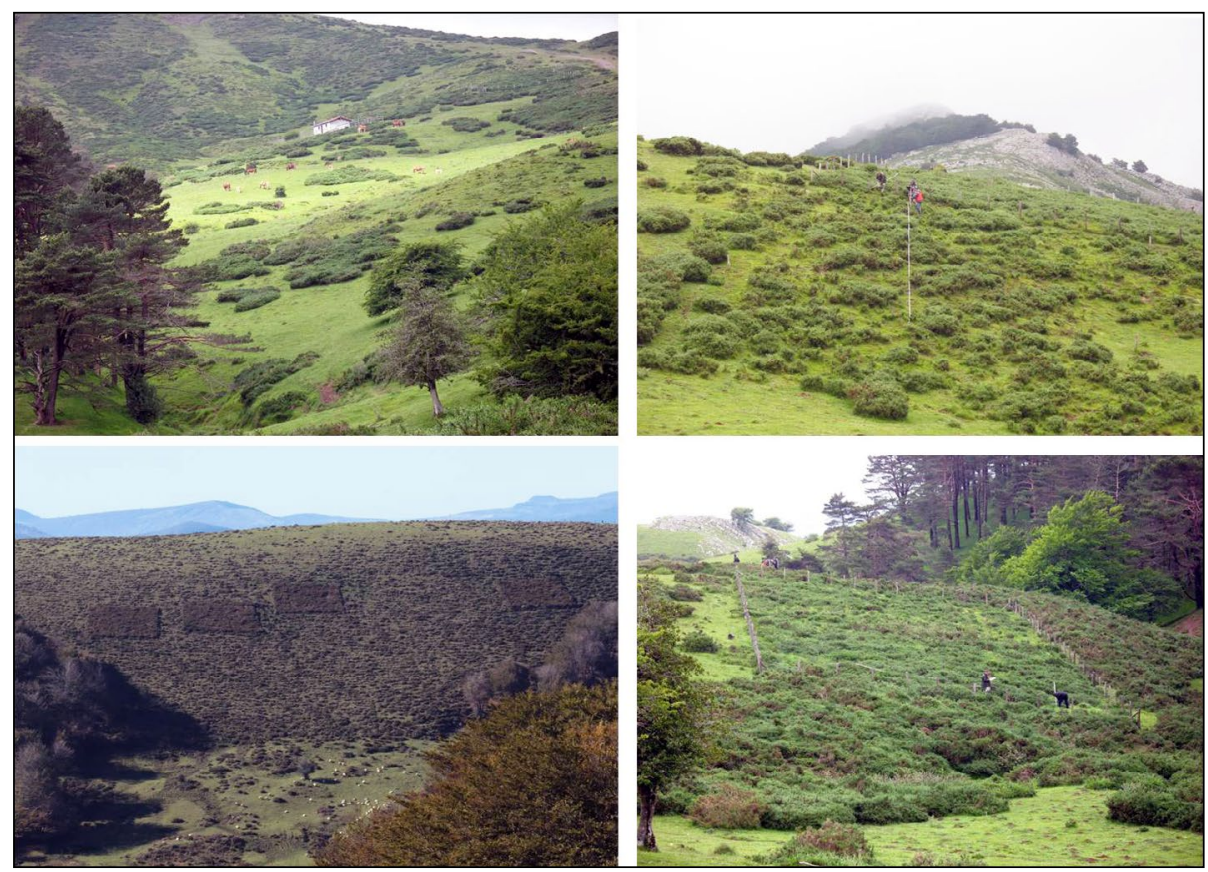

Figure 2. General view (on the left) and plot detail (on the right) of Sierra de Aralar (up) and Belate (below) study areas. 
Both territories are strongly influenced by the proximity of the Cantabrian Sea, and the E-W disposition of the relief exerts a screen effect to the moisture-laden winds coming from the NW, so in the north-facing slopes fogs and precipitations are frequent, while in the southeast parts climatic continentality increases. The annual precipitations range between 1400 and $2000 \mathrm{~mm}$ (ombrotype between wet and hyper-humid) and do not show summer drought. The average temperature ranges between 13 and $14^{\circ} \mathrm{C}$. It is possible to differentiate a coline (mesic-temperate) and a montane (over-temperate) belt, with the boundary between both around 600-650 m altitude.

The potential vegetation of the montane belt, in which the study has been carried out, corresponds to the ombrophilous and basophilous Cantabrian beechwoods in Sierra de Aralar (Carici sylvaticae - Fagetum sylvaticae), and ombrophilous and acidophilous beechwoodsin Belate (Saxifrago hirsutae - Fagetum sylvaticae). The shrub is dominated by the "otea" or "argoma" (Ulex gallii Planch.) with some heather (Daboecia cantabrica (Huds.) K. Koch, Erica vagans L., E. tetralix L., E. cinerea L. and Calluna vulgaris (L.) Hull.) with low plant cover. Forming a mosaic with the shrubs, the predominant pasture in Aralar corresponds to the association Jasiono laevis-Danthonietum decumbentis Loidi 1983. The most abundant plants in this pasture are Festuca nigrescens Lam. subsp. microphylla (Saint-Yves) MarkgrafDanenb., Trifolium repens L. and Agrostis capillaris L. In Belate, acidophilous pastures of Agrostis curtisii Kerguélen (Carici piluliferae-Agrostietum curtisii Darquistade et al., 2004) predominate, and Molinia caerulea (L.) Moench and Avenula lodunensis (Delastre) Kerguélen are very frequent. In addition, patches of megaforbs, birchs and jew trees are found in smaller areas and, especially in Belate, peat bogs and similar plant communities are found in the flooded depressions, where most of the flora with high conservation interest grows.

The main use of both territories is pastoral (around 900 ha of grasslands in Aralar and 270 ha in Belate), with mixed livestock composed of cattle (350 and 176 heads in each territory, respectively), sheep (7600 and 650 heads, respectively) and equine (600 and 74 heads, respectively). This results in a stocking rate (LU, Lifestock Unit) between 1.3 (in Aralar) and 2.3 (in Belate) LU / ha ( $1 \mathrm{LU}=1 \mathrm{cow}=$ 1 equine; 1 sheep $=0.15 \mathrm{LU}$ ), which has been stable in the last decade. Cattle graze the area between 180 and 210 days a year (from the middle of May to the middle of October or the beginning of November).

Both territories are, to a large extent, public property and are included in Special Conservation Zones (ZEC). In addition, Aralar has 93\% of its territory covered by the "Union of Aralar", an entity with long tradition and legal personality in force since the $10^{\text {th }}$ century, and recognized in the current legislation of Navarra.

\section{Methods}

On east facing gentle slopes (slope gradient between 14\% and 27\%) of Aralar (between 1100 and $1190 \mathrm{~m}$ a.s.l.) and Belate (between 915 and $935 \mathrm{~m}$ a.s.1.), 16 
plots of $20 \times 20 \mathrm{~m}$ ( 8 plots in each area) were delimited over uniform vegetation with a shrub mosaic dominated by argoma and pasture of the aforementioned plant communities. The ground was completely covered by vegetation and litter. The experimental protocol responded to three treatments carried out between March and April 2007 by the forestry service of the Government of Navarra: the burning "shrub by shrub" clearing and two mechanical shrub clearing with chains (one at a height of $10 \mathrm{~cm}$ above the ground -"at $10 \mathrm{~cm}$ "- and another at ground level -"at ground"-). Both in the mechanically cleared and burned treatments, the remains were left on the ground. For each of the three treatments, two contiguous plots were marked in each zone, separated from each other by about $7 \mathrm{~m}$. One was closed with barbed wire to prevent the entry of livestock and the other remained open to grazing (Gómez García et al., 2011). Two additional plots (closed and open to grazing) were marked in a control area with the original vegetation untreated.

The height and coverage of shrub vegetation was measured in three linear transects of $20 \mathrm{~m}$, parallel and equidistant in each plot, with 100 points per transect (one contact every $20 \mathrm{~cm}$ ). The sampling was carried out just before the burning and clearing treatments and, after the treatments, five times in Aralar and four times in Belate, between 2007 and 2013.

\subsection{Statistical analysis}

The variables "cover" and "height" of the shrubs were transformed by its elevation to a power, so that its distribution was normal; however, the means of the untransformed variable are shown in the Results section. Normality has been evaluated by the Kolmogorov-Smirnov test, taking into account that the number of observations was 440 .

The comparison of means of "cover" and "height" of the shrubs in the burned plots vs. not burned, and grazed vs. no grazed was done with the Student's test. The comparison of the means over the 7 years of study was done with the Tukey test. The evaluation of the effect of mechanical clearing was carried out using a General Linear Model (PROC GLM, SAS 9.4) with two fixed effects: type of clearing ("at $10 \mathrm{~cm}$ " and "at ground") and time (years before and following the treatment); the differences between the levels (type of clearing and years, respectively) of the fixed effects were evaluated by the Tukey test.

\section{Results}

\subsection{Effect of burning}

The shrub coverage did not show significant differences between the burned and unburned plots in the two study areas after the 7 years of treatment (Table 1). With respect to height, only in Aralar there were significant differences between the burned areas and the control ones. In both Aralar and Belate, after the third year of study, it was not possible to distinguish $(p>0.05)$ the cover and height of the shrub from those prior to the action. 
Gómez et al.

Table 1. Means and standard deviation of shrub cover (\%) and shrub height (cm) in the burned and unburned plots, in the two study areas -Aralar and Belate-after 7 years of treatment. $t$ :

Student's test statistic; $p$ : p-value.

\begin{tabular}{|c|c|c|c|c|c|c|c|c|}
\hline Zones & \multicolumn{2}{|c|}{ Aralar } & \multicolumn{2}{c|}{ Probability } & \multicolumn{2}{c|}{ Belate } & \multicolumn{2}{c|}{ Probability } \\
\hline Variables & Burned & Unburned & $\mathbf{t}$ & $\mathbf{p}$ & Burned & Unburned & $\mathbf{t}$ & $\mathbf{p}$ \\
\hline Shrub cover $(\%)$ & $77.02 \pm 6.45$ & $80.60 \pm 7.36$ & 1.771 & 0.083 & $\begin{array}{c}53.15 \pm \\
20.95\end{array}$ & $58.15 \pm 8.88$ & 0.917 & 0.370 \\
\hline Shrub height $(\mathrm{cm})$ & $40.73 \pm 22.51$ & $73.55 \pm 10.03$ & 5.034 & $<0.001$ & $\begin{array}{c}36.45 \pm \\
30.26\end{array}$ & $45.96 \pm 8.04$ & 1.066 & 0.304 \\
\hline
\end{tabular}

\subsection{Effect of grazing on burned areas}

Grazing on burned plots significantly reduced shrub cover in the two study areas, while no differences in height were observed (Table 2 and Fig. 3 ).

Table 2. Means and standard deviation of shrub cover (\%) and shrub height (cm) in the burned plot under grazing and no grazing conditions in the two study areas-Aralar and Belate-after 7 years of treatment. $t$ : Student's test statistic; $p:$-value.

\begin{tabular}{|c|c|c|c|c|c|c|c|c|}
\hline Zones & \multicolumn{2}{|c|}{ Aralar } & \multicolumn{2}{c|}{ Probability } & \multicolumn{2}{c|}{ Belate } & \multicolumn{2}{c|}{ Probability } \\
\hline Variables & Grazed & Ungrazed & t & p & Grazed & Ungrazed & t & p \\
\hline Shrub cover $(\%)$ & $66.07 \pm 17.19$ & $78.85 \pm 7.09$ & 4.667 & $<0.001$ & $\begin{array}{c}37.07 \pm \\
19.51\end{array}$ & $55.85 \pm 15.59$ & 4.498 & $<0.001$ \\
\hline Shrub height $(\mathrm{cm})$ & $67.21 \pm 23.44$ & $58.24 \pm 23.59$ & -0.564 & 0.123 & $\begin{array}{c}37.03 \pm \\
21.19\end{array}$ & $39.78 \pm 24.91$ & 0.351 & 0.728 \\
\hline
\end{tabular}

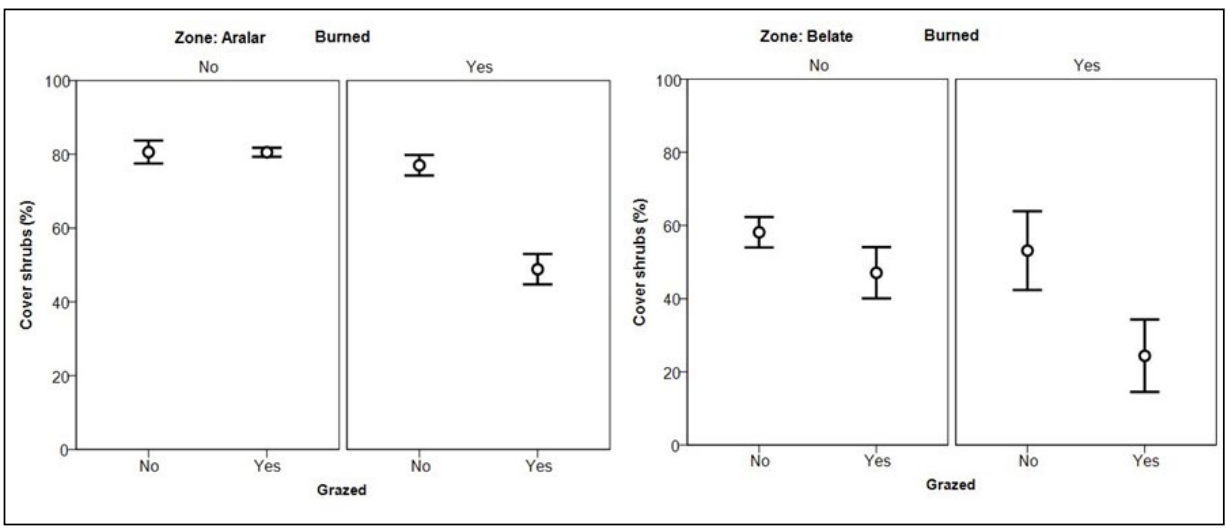

Figure 3. Confidence interval at $95 \%$ of the shrub cover in the burned and control plots under grazing and no grazing conditions after 7 years of treatment in Aralar and Belate.

\subsection{Effect of mechanical clearing}

Mechanical clearing showed a significant effect on both cover and shrub height in the two study areas (Table 3). In terms of cover, the cleared plots "at ground" level showed 
a significantly lower value than the cleared "at $10 \mathrm{~cm}$ " and the control plots, while the "at $10 \mathrm{~cm}$ " plots showed a significantly lower coverage than the control plots. Regarding height, in Aralar, the "at ground" and "at $10 \mathrm{~cm}$ " plots showed a significantly lower height than that observed in the control plots, but there were not significant differences between them; in Belate, the "at ground" plots showed significantly lower heights than the "at $10 \mathrm{~cm}$ " and "control" plots, and the "at $10 \mathrm{~cm}$ " plots showed significantly lower heights than the control plots.

Table 3. Least square means of shrub cover (\%) and shrub height $(\mathrm{cm})$ in the control and mechanically cleared plots in the two study areas-Aralar and Belate-after 7 years of the treatment. SED: standard error of the difference of means; $p$ : $p$-value. For coverage: $R^{2}$ ad Aralar $=0.872 ; R_{a d}^{2}$ Belate $=0.534 ;$ for height $: R^{2}$ Ad Aralar $=0.879 ; R_{a d}^{2}$ Belate $=0.858$. Different letters indicate significant differences $(p<0.05)$.

\begin{tabular}{|c|c|c|c|c|c|c|c|c|c|c|}
\hline Zones & \multicolumn{3}{|c|}{ Aralar } & \multicolumn{2}{c|}{ Probability } & \multicolumn{3}{c|}{ Belate } & \multicolumn{3}{c|}{ Probability } \\
\hline Variables & Control & $\begin{array}{c}\text { At } \\
\mathbf{1 0} \mathbf{~ c m}\end{array}$ & $\begin{array}{c}\text { At } \\
\text { ground }\end{array}$ & SED & $\mathbf{p}$ & Control & $\begin{array}{c}\text { At 10 } \\
\text { cm }\end{array}$ & $\begin{array}{c}\text { At } \\
\text { ground }\end{array}$ & SED & p \\
\hline Shrub cover $(\%)$ & $84.38 \mathrm{c}$ & $43.64 \mathrm{~b}$ & $32.65 \mathrm{a}$ & 3.11 & $<0.001$ & $52.92 \mathrm{c}$ & $43.08 \mathrm{~b}$ & $37.18 \mathrm{a}$ & 3.00 & $<0.001$ \\
\hline Shrub height $(\mathrm{cm})$ & $78.11 \mathrm{~b}$ & $37.65 \mathrm{a}$ & $33.57 \mathrm{a}$ & 3.46 & $<0.001$ & $46.17 \mathrm{c}$ & $30.05 \mathrm{~b}$ & $25.82 \mathrm{a}$ & 2.67 & $<0.001$ \\
\hline
\end{tabular}

The effect of the time elapsed during the study was significant in both coverage and shrub height (Table 4 and Fig. 4). Regarding coverage, in Aralar, the coverage values tended to increase towards the previous situation although in the seventh year it was still $20 \%$ below the previous values; in Belate, in the sixth year the previous coverage was already significantly exceeded. In terms of height, in Aralar, from the fifth year the height of the previous situation was reached whereas in Belate, the previous height was reached in the sixth year.

Table 4. Least square means of shrub cover (\%) and shrub height $(\mathrm{cm})$ in the control and mechanically cleared plots in the two study areas-Aralar and Belate-throughout the 7 years of study. SED: standard error of the difference of means; $p$ : $p$-value. Different letters indicate significant differences $(p<0.05)$.

\begin{tabular}{|c|c|c|c|c|c|c|c|c|c|}
\hline \multirow[b]{2}{*}{ Aralar } & \multicolumn{7}{|c|}{ Time } & \multicolumn{2}{|c|}{ Probability } \\
\hline & $\begin{array}{c}\text { Previ- } \\
\text { ous }\end{array}$ & Year 1 & Year 2 & Year 3 & Year 5 & Year 6 & Year 7 & SED & $p$ \\
\hline Shrub cover (\%) & $80.00 \mathrm{c}$ & $36.77 \mathrm{~b}$ & $43.28 \mathrm{a}$ & $51.39 \mathrm{ab}$ & $51.72 \mathrm{a}$ & - & $58.16 \mathrm{ab}$ & 5.56 & $<0.001$ \\
\hline Shrub height $(\mathrm{cm})$ & $55.83 \mathrm{~b}$ & $27.19 \mathrm{a}$ & $44.51 b$ & $54.42 \mathrm{~b}$ & $55.89 \mathrm{~b}$ & & $60.82 \mathrm{~b}$ & 5.81 & $<0.001$ \\
\hline \multicolumn{10}{|l|}{ Belate } \\
\hline Shrub cover $(\%)$ & $44.16 \mathrm{a}$ & $36.90 \mathrm{a}$ & $39.91 \mathrm{a}$ & $45.28 \mathrm{a}$ & - & $55.72 b$ & - & 4.71 & $<0.001$ \\
\hline Shrub height $(\mathrm{cm})$ & $42.92 \mathrm{c}$ & $20.87 \mathrm{a}$ & $28.33 b$ & $31.66 \mathrm{~b}$ & & $46.29 \mathrm{c}$ & & 3.86 & $<0.001$ \\
\hline
\end{tabular}




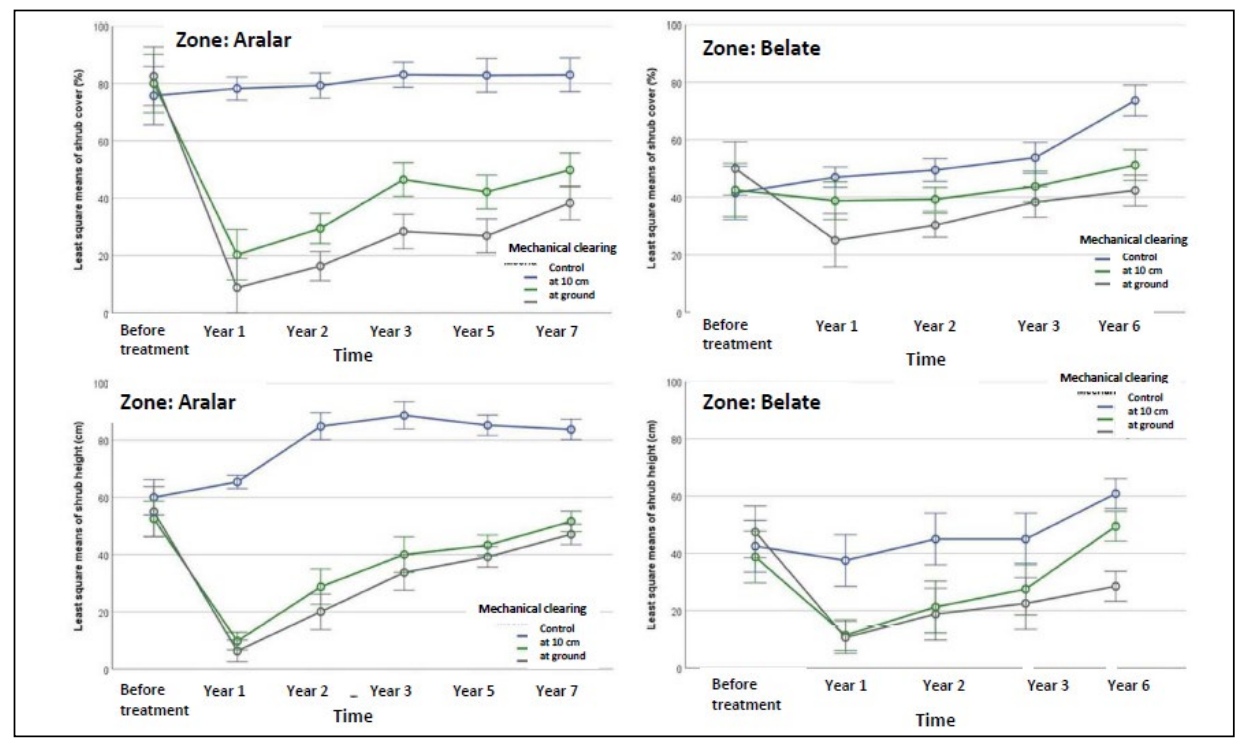

Figure 4. Least square means of shrub cover and shrub height in the control and mechanically cleared (at $10 \mathrm{~cm}$ above ground and at ground level) plots in the two study areas, Aralar and Belate, throughout the 7 years of study.

\subsection{Effect of grazing on mechanical cleared areas}

Grazing on cleared plots significantly reduced cover in the two study areas, but no differences in shrub height were observed (Table 5). On the other hand, the effect of grazing seems to be different according to the original cover (Fig. 5): in Aralar, with a control cover of over $80 \%$, grazing had no incidence, while with a shrub covers under $60 \%$, such as those in "at $10 \mathrm{~cm}$ " and "at ground" clearing plots in Aralar, and all the plots in Belate, grazing exerted a significant reduction in shrub cover.

Table 5. Means and standard deviation of shrub cover (\%) and shrub height (cm) in the mechanical cleared plots under grazing and no grazing conditions in the two study areas -Aralar and Belate-after 7 years of treatment. t: Student's test statistic; $p$ : p-value.

\begin{tabular}{|c|c|c|c|c|c|c|c|c|}
\hline Zones & \multicolumn{2}{|c|}{ Aralar } & \multicolumn{2}{c|}{ Probability } & \multicolumn{2}{c|}{ Belate } & \multicolumn{2}{c|}{ Probability } \\
\hline Variables & Grazed & Ungrazed & $\mathbf{t}$ & $\mathbf{p}$ & Grazed & Ungrazed & t & p \\
\hline Shrub cover $(\%)$ & $48.58 \pm 29.29$ & $61.48 \pm 25.47$ & 2.512 & 0.013 & $\begin{array}{c}40.26 \pm \\
13.56\end{array}$ & $49.81 \pm 11.58$ & 3.653 & $<0.001$ \\
\hline Shrub height $(\mathrm{cm})$ & $54.18 \pm 30.35$ & $52.90 \pm 25.86$ & -0.218 & 0.828 & $\begin{array}{c}35.15 \pm \\
20.62\end{array}$ & $31.47 \pm 15.09$ & -0.735 & 0.466 \\
\hline
\end{tabular}




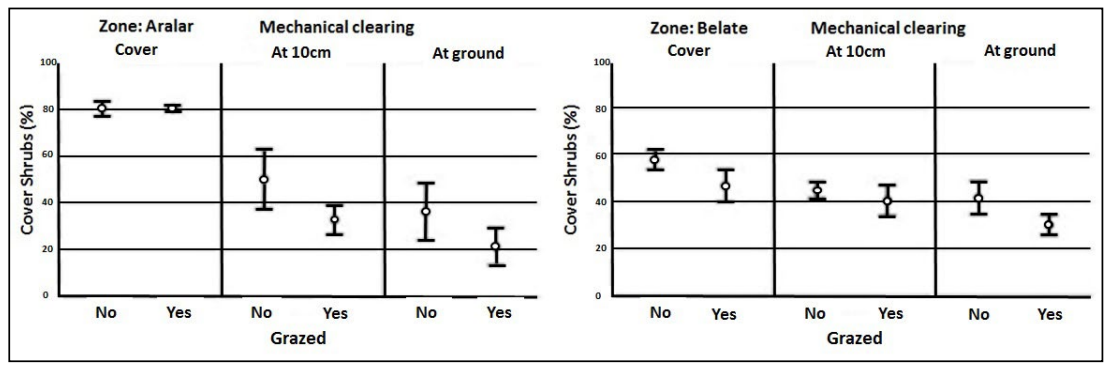

Figure 5. Interval of confidence at $95 \%$ of the shrub cover in the mechanical cleared and control plots, under grazing and no grazing conditions, after 7 years of treatment in Aralar and Belate.

\section{Discussion}

The cessation or reduction of grazing has been proposed as the main cause of shrub encroachment in the Mediterranean region (Zarovali et al., 2007; Maestre et al., 2009). However, in the study area, with a marked Atlantic influence, argoma shrub persists despite the maintenance and even the temporary increase of the stocking rate suggesting that grazing by itself is not enough for stopping shrub expansion, as it has been observed in other nearby Mediterranean mountains (Bartolomé et al., 2000).

After both the burning and clearing treatments, the argoma has shown a vigorous and rapid resprouting capacity from the following spring, exceeding the average value that has been attributed to the species and its congeners in Galicia (Reyes and Casal, 2008). An even more rapid regrowth response for the same species after the same treatments has been described in similar plant and climate communities in Cantabria (Fernández Filgueira et al., 2013), with an average cover recovery of $74 \%$ of the initial coverage after two years (after clearing with fire and stripping), and a recovery of the total shrub cover in the same period, close to $95 \%$ after clearing with crushing and $99.5 \%$ after burning.

Our results showed that the effect of intense grazing results in a temporary delay in shrub recovery, which will be reduced with reduced stocking rates (the usual ones in many nearby territories) that allow the herbivores to select areas with better pasture than those recently intervened. However, clearing seems to attract grazing in all cases and, to the contrary, the (open) control plots have not shown any signs of grazing. On the other hand, initial shrub cover seems relevant for the grazing effect, since grazed plots with less coverage have shown a greater delay in the regrowth.

Both our results and those of similar experiments with the same plant question the efficacy of these treatments in the improvement of pastures in the medium and the long term (Fig. 6). Neither the clearing nor the fire seem to drastically affect the underground organs of the argoma, as shown by its persistence and renewal vigor, together with an abundant post-fire germination of its seeds (Reyes and Casal, 2008). The time of the burning (winter) is the most suitable considering both the protection of the soil (Gehú 
and Gehú-Frank, 1960; Montserrat, 1978; Badía et al., 2017; Alcañiz et al., 2018) and the easy combustion of the plant due to the absence of sap circulation. However, the humid and cold soil during this season can provide greater protection for buds and roots (Badía et al., 2017). In addition, the dense structure of the underground organs of the shrub prevents the establishment of herbaceous grass or limits the germination to some annual plants with little pastoral interest and short life after the treatments (Calvo et al., 2002).
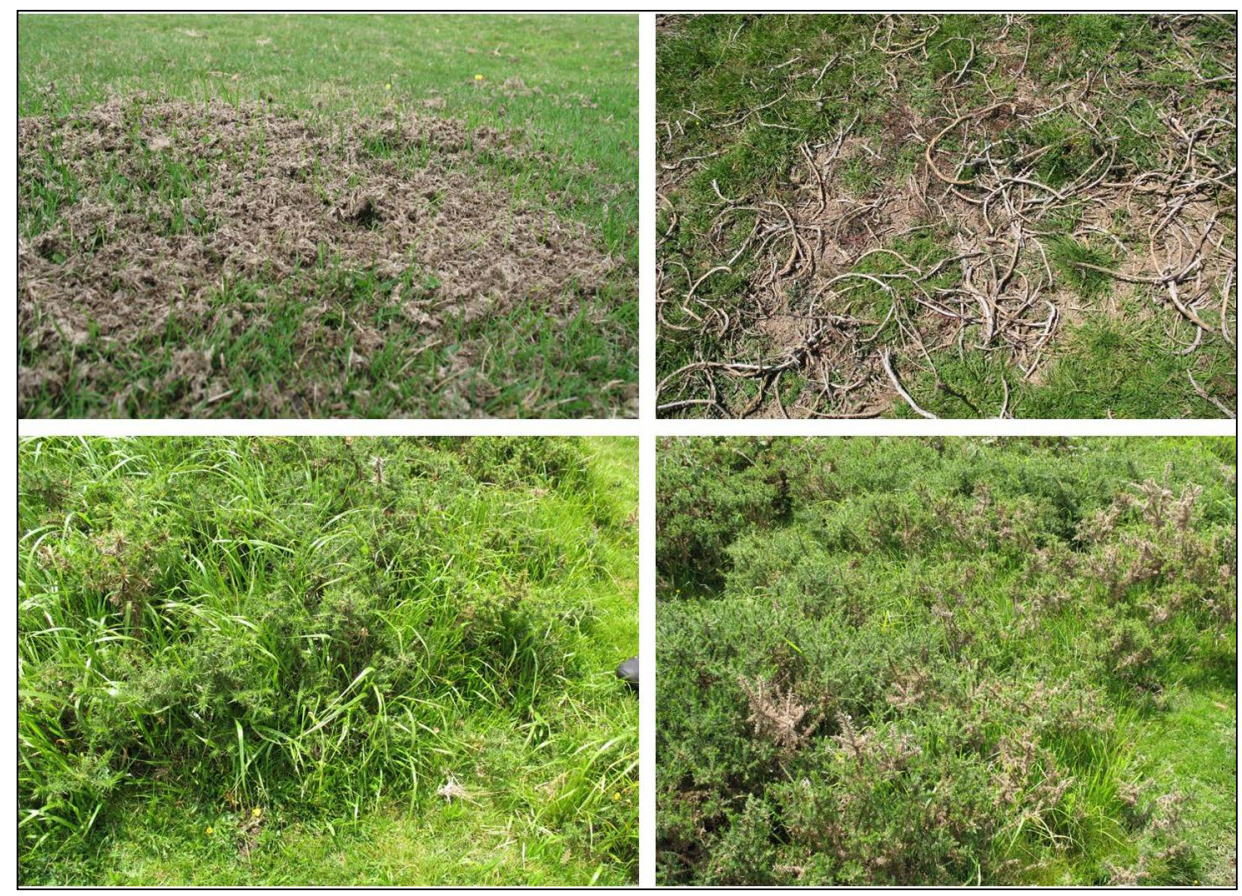

Figure 6. Different phases of vegetation succession after shrub clearing.

The resilience shown by the argoma shrub seems to demand a frequent repetition of the treatments, which are not always easy to justify and finance and perhaps are ineffective in the improvement of the pasture if they are not accompanied by other livestock management measures. Considering these uncertainties and based on the observations of the field work and the contrasted opinions of farmers and shepherds (Lizaur and Gómez García, 2007, 2008), we suggest considering the following complementary or corrective measures to improve the treatments:

(i) The planning of the "pasture demand" in the short and medium term should guide the intensity and frequency of the clearing actions in order to address their economic and ecological justification. In any case, shrub removal should be prioritized in territories with very active livestock (with a stocking rate of at least 1.5 LU / ha in montane pastures with Atlantic climate). With lower 
stocking rates, other actions aiming at a better temporal and spatial livestock use (for example, the use of temporary fences or electric shepherds) should be prioritized, focusing on the prevention of new shrub encroachment, as discussed below.

(ii) Mechanical clearing has shown greater efficacy than fire. The level of clearing "at $10 \mathrm{~cm}$ " seems to be sufficient compared to "at ground" level, since the difference in regrowth is minimal. Moreover, its execution is easier and minimizes the risk of soil erosion. As for the periodicity, a clearing repeated annually or every two years could be more effective than a less frequent one as it favors a continuous weakening of the corm. The annual clearing of the zenith regrowths seems advisable, since browsing has not diminished the height growth of the argoma. The effectiveness of a temporary delay of mechanical clearing (not fire!) until the beginning of flowering (in May, shortly before the entry of cattle) could be tested since this is the time of the greatest metabolic expense of the argoma and the treatment would be more adverse for its recovery.

(iii) The treatments should be prioritized in the smaller and lower cover shrub patches (those that form "islands" between the grass), while in the more extensive and dense masses, the treatment could be limited to the margins and to the opening of corridors to facilitate the prowling of the livestock, its transit to the "pastos rasos" and the browse of regrowths that may precede a subsequentmore intense clearing.

(iv) In the recently cleared areas, grazing (with short-term heavy stocking rates) must be intensified immediately, forcing the passage of livestock, its trampling and manuring (for instance, through the supply of salt, water or with temporary closures) to promote breakage or consumption of young shoots. Without this frequency, there will be a risk of favoring the expansion of undesirable grasses for grazing and precursors of shrub recolonization, such as Brachypodium rupestre (Host) Roemer \& Schultes and Agrostis curtisii Kerguélen (Montserrat, 1978).

(v) The former measure could also be facilitated by intensifying and prolonging the stay of the large cattle during the winter and early spring, when the regrowth of the shrub coincides with a lower supply of herbaceous grass and forces its consumption. The browsing of the young regrowth, which slows the lateral expansion of the argoma, is only noticeable with equine cattle and, to a lesser extent, with rustic cattle (Montserrat, 1996; Osoro et al., 2005). Winter grazing should be excluded in the steepest areas to protect the soil and respect forest regeneration.

(vi) If mechanical clearing is not possible, it is necessary to reconsider the traditional use of fire (and its rhythms and procedures, different from the current prescribed burns) for the maintenance of pastures and evaluate its usefulness and its adaptation to the new environmental and socio-economic 
framework (Metailié, 1981, 2006). In this regard, it must be noted that many mountain pastoral landscapes with remarkable diversity values of habitats and species, now protected by legal frameworks, are the result of an ancestral use of fire that is now severely restricted or even forbidden, perhaps sometimes without sufficient reflection. In any case, the burning should be limited to the winter season, applied with intensity and annual repetition, avoided in summits, ridges or rocky outcrops and limited to the smallest spots that interrupt access to the best pastures, that is to say, those located at the bottom of valleys and slopes with low slope gradient (Montserrat, 1978).

(vii) Shrub expansion is preceded, in general, by a thickening of herbaceous grasslands belonging to the domain of hard-leaf and little palatable grasses for their content in silica and low pastoral value (mainly Agrostis curtisii, Brachypodium rupestre, Avenula lodunensis and Molinia coerulea). Intensifying the stocking rate in areas dominated by these plants, for instance by continuous grazing, encourages their substitution by Agrostis capillaris, Festuca nigrescens, Poa spp., Trifolium spp., Lotus corniculatus L., etc. and could be an effective and fast measure to improve grasslands (Montserrat, $1988,1996)$ and to prevent shrub encroachment.

(viii) In the most inaccessible patches, reforestation could be carried out with trees of the surrounding forest (Sorbus, Acer, Fraxinus, Taxus, Crataegus), alternating those of rapid and slow growth, such as ash and yew. The development of trees forming small islets in the pasture will compete with shrub encroachment and will tend to replace it. The trees will offer shade that will attract livestock and will increase the heterogeneity of the landscape and diversity at different scales.

(ix) Finally, periodic monitoring (for example every 5 years) of the shrubland surface, the grassland structure and its forage quality should be done to guarantee the continuity of the treatments or to adopt the corrections that are considered convenient.

\section{Conclusions}

Shrub encroachment in the Navarrese mountains of the Sierra de Aralar and Belate has not been caused by a decrease in stocking density, although it could be related to changes in its management. Regarding shrub control, mechanical clearing has shown greater efficacy than burning in delaying argoma shrubs (Ulex gallii) recovery. Clearing at ground level has not shown greater efficiency than clearing at a height of $10 \mathrm{~cm}$. This second procedure is simpler and reduces soil movement and the risk of soil erosion. In any case, both treatments, as currently applied, appear to be ineffective in the medium term in reversing the process of shrub encroachment. In the light of our study, it seems advisable to increase the stocking rate locally, extend the grazing period and facilitate the transit of livestock to the best grazing areas. 


\section{Acknowledgements}

This work was financed by the Department of Environment, Territorial Planning and Housing of the Government of Navarre. We thank the engineers Pablo Muñoz and Mikel Repáraz for their interest in its development and for their help in organizing the data. Elena Tello helped us in the data management and first data treatment.

\section{References}

Alberdi Collantes, J.C. 2003. Políticas agroambientales y ganadería en los montes de utilidad pública del País Vasco. Papeles de Geografía 38, 5-26.

Alcañiz, M., Outeiro,L., Francos, M.,Úbeda,X. 2018. Effects of prescribed fires on soil properties: a review. Science of The Total Environment 613-614, 944-957. https://doi.org/ 10.1016/j. scitotenv.2017.09.144.

Allred, B.W. 1949. Distribution and Control of Several Woody Plants in Texas and Oklahoma. Journal of Range Management 2, 17-29. https://doi.org/10.2307/3893829.

Archer, S.R. 2009. Rangeland Conservation and Shrub Encroachment: New Perspectives on an Old Problem. In: J. T. du Toit, R. Kock, J.C. Deutsch (Eds.), Wild Rangelands: Conserving Wildlife While Maintaining Livestock in Semi-Arid Ecosystems. John Wiley \& Sons, Ltd., Chichester, pp. 53-97.

Archer, S., Schimel, D.S., Holland, E.A. 1995. Mechanisms of shrubland expansion: land use, climate or CO2? Climatic Change 29, 91-99. https://doi.org/10.1007/BF01091640.

Armas-Herrera, C.M., Martí, C., Badía, D., Ortiz-Perpiñá, O., Girona García, A., Porta, J. 2016. Immediate effects of prescribed burning in the Central Pyrenees on the amount and stability of topsoil organic matter. Catena 147,238-244.https://doi.org/10.1016/j.catena.2016.07.016.

Aseginolaza, C., Gómez, D., Lizaur, X., Montserrat, G., Morante, G., Salaverria, M.R., UribeEchebarria, P.M. 1988. Vegetación de la Comunidad Autónoma del País Vasco. Servicio Central de Publicaciones del Gobierno Vasco, Vitoria-Gasteiz.

Badía, D., López-García, S., Marti, C., Ortiz-Perpiñá, O., Girona-García, A., Casanova-Gascón, J. 2017. Burn effects on soil properties associated to heat transfer under contrasting moisture content. Science of The Total Environment 601-602, 1119-1128. https://doi.org/10.1016/j. scitotenv.2017.05.254.

Bartolomé, J., Franch, J., Plaixats, J., Seligman, N.G. 2000. Grazing alone is not enough to maintain landscape diversity in the Montseny Biosphere Reserve. Agriculture, Ecosystems \& Environment 77, 267-273. https://doi.org/10.1016/S0167-8809(99)00086-9.

BON (Boletín Oficial de Navarra) 2006. Orden foral 432/2006, de 21 de noviembre, del Consejero de Medio Ambiente, Ordenación del Territorio y Vivienda, por la que se regula el régimen excepcional de concesión de autorizaciones para el uso del fuego como tratamiento de mejora de los pastos naturales y para la realización de trabajos selvícolas.

Briggs, J.M., Knapp, A.K., Blair, J.M., Heisler, J.L., Hoch, G.A., Lett, M.S., McCarron, J.K. 2005. An Ecosystem in Transition: Causes and Consequences of the Conversion of Mesic Grassland to Shrubland. BioScience 55, 243-254. https://doi.org/10.1641/0006-3568(2005).

Burrows, W.H., Beale, I.F., Silcock, R.G., Pressland, A.J. 1990. Prediction of tree and shrub population changes in a semi-arid woodland. In: J.C. Tothill, J.J. Mott (Eds.), Ecology and Management of the Worlds Savannas. Australian Academy of Science, Canberra, pp. 207211.

Calvo, L., Tárrega, R., De Luis, E. 2002. Secondary succession after perturbations in a shrubland community. Acta Oecologica 23, 393-404. https://doi.org/10.1016/S1146-609X(02)01164-5. 
Calvo, L., Tárrega, R., Luis, E., Valbuena, L., Marcos, E. 2005. Recovery after experimental Navarra.

Calvo, L., Tárrega, R., Luis, E., Valbuena, L., Marcos, E. 2005. Recovery after experimental cutting and burning in three shrub communities with different dominant species. Plant Ecology 180, 175-185. https://doi.org/10.1007/s11258-005-0200-z.

Coetzee, B.W.T., Tincani, L., Wodu, Z., Mwasi, S.M. 2008. Overgrazing and bush encroachment by Tarchonanthus camphoratus in a semi-arid savanna. African Journal of Ecology 46, 449451. https://doi.org/10.1111/j.1365-2028.2007.00842.x.

Dolman, P.M., Sutherland, W.J. 1992. The ecological changes of breckland grass healths and the consequences of management. Journal of Applied Ecology 29, 402-413. https://doi. org/10.2307/2404509.

Eldridge, D.J., Bowker, M.A., Maestre, F.T., Roger, E., Reynolds, J.F., Whitford, W.G. 2011. Impacts of shrub encroachment on ecosystem structure and functioning: towards a global synthesis. Ecology Letters 14, 709-722. https://doi.org/10.1111/j.1461-0248.2011.01630.x.

Fernández Filgueira, C., Vega Hidalgo, J.A., Fontube Lliteras, T. 2013. Cambios en la cobertura vegetal después de tratamientos preventivos de incendios forestales en dos áreas de matorral del Norte de España. In: G. Montero González, M. Guijarro Guzmán et al. (Eds.), Actas $6^{o}$ Congreso forestal español. Sociedad de Ciencias Forestales, Vitoria-Gasteiz.

Fernández-Giménez, M.E., Fillat, F. 2012. Pyrenean pastoralists observations of environmental change: an exploratory study in Los Valles Occidentales of Aragón. Pirineos 163, 143-163. http://doi.org/10.3989/Pirineos.2012.167007.

Gehu, J.M., Gehu-Franck, J. 1960. L'evolution du sol et de la végétation, après incendie, dans une lande bretonne. Bulletin du Laboratoire Maritime de Dinard 46, 42-77.

Gómez García, D., Aguirre, A.J., Lizaur Xukía, X. 2011. Recuperación del matorral tras desbroce mecánico y quema en pastos de la sierra de Aralar y Belate (Navarra). In: C. López-Carrasco, M.P. Rodríguez-Rojo, A. San Miguel, F. Fernández-González, S. Roig (Eds.), Pastos, Paisajes Culturales entre Tradición y nuevos Paradigmas del siglo XXI. SEEP, Toledo, pp. 133-138.

Hobbs, R.J., Mooney, H.A. 1986. Community Changes following Shrub Invasion of Grassland. Oecologia 70, 508-513. https://doi.org/10.1007/BF00379896.

Hochtl, F., Lechringer, S., Konold, W. 2005. Wilderness: what it means when it becomes a reality - a case study from the southwestern Alps. Landscape and Urban Planning 70, 85-95. https://doi.org/10.1016/j.landurbplan.2003.10.006.

Iñiguez, J., Sánchez-Carpintero, I., Val, R., Vidal, M., Vitoria, G., Peralta, J. 1990. Mapa de suelos de Navarra. Escala 1/50.000. Hojas Hoja 90-Sumbilla y 114-Alsasua. Servicio de Publicaciones de la Universidad de Navarra. Departamento de Edafología, Universidad de Navarra, Pamplona.

Knapp, A.K., Beier, C., Briske, D.D., Classen, A.T., Luo, Y., Reichstein, M., Smith, M.D., Smith, S.D., Bell, J.E., Fay, P.A., Heisler, J.L., Leavitt, S.W., Sherry, R., Smith, B., Weng, E. 2008. Consequences of More Extreme Precipitation Regimes for Terrestrial Ecosystems. BioScience 58, 811-821. https://doi.org/10.1641/B580908.

Lasanta, T., Arnáez, J., Errea, M.P., Ortigosa, L., Ruiz Flaño, P. 2009 Mountain pastures, environmental degradation, and landscape remediation: The example of a Mediterranean policy initiative. Applied Geography 29, 308-319. https://doi.org/10.1016/j.apgeog.2008.09.006.

Lasanta, T., Vicente-Serrano, S.M., Arnáez, J. 2011. La revegetación en las montañas españolas ¿dejar hacer o intervenir en el territorio? Geographicalia 59-60, 199-211. https://doi. org/10.26754/ojs_geoph/geoph.201159-60832.

Lasanta, T., Nadal-Romero, E., Arnáez, J. 2015. Managing abandoned farmland to control the impact of re-vegetation on the environment. The state of the art in Europe. Environmental Science \& Policy 52, 99-109. https://doi.org/10.1016/j.envsci.2015.05.012. 
Lasanta, T., Nadal-Romero, E., Errea, P., Arnáez, J. 2016. The effect of landscape conservation measures in changing landscape patterns: a case study in Mediterranean mountains. Land Degradation \& Development 27, 373-386. https://doi.org/10.1002/ldr.2359. .

Lizaur, X., Gómez García, D. 2007. Evolución de la vegetación en sendas áreas de Belate y Sierra de Aralar, tras el desbroce mecánico y quema controlada para mejora de pastos (I). Informe inédito para el Departamento de Medio Ambiente, Ordenación del territorio y Vivienda del Gobierno de Navarra.

Lizaur, X., Gómez García, D. 2008. Evolución de la vegetación en sendas áreas de Belate y Sierra de Aralar, tras el desbroce mecánico y quema controlada para mejora de pastos (II). Informe inédito para el Departamento de Medio Ambiente, Ordenación del territorio y Vivienda del Gobierno de Navarra.

Liu, F., Archer, S.R., Gelwick, F., Bai, E., Boutton, T.W., Wu, X.B. 2013. Woody Plant Encroachment into Grasslands: Spatial Patterns of Functional Group Distribution and Community Development. PLOS ONE 8 (12): e84364. https://doi.org/10.1371/journal. pone.0084364.

Maestre, F.T., Bautista, S., Cortina, J. 2003. Positive, negative, and net effects in grass-shrub interactions in mediterranean semiarid grasslands. Ecology 84, 3186-3197. https://doi. org/10.1890/02-0635.

Maestre, F.T., Bowker, M.A., Puche, M.D., Belén Hinojosa, M., Martínez, I., García-Palacios, P., Castillo, A.P., Soliveres, S., Luzuriaga, A.L., Sánchez, A.M., Carreira, J.A., Gallardo, A., Escudero, A. 2009. Shrub encroachment can reverse desertification in semi-arid Mediterranean grasslands. Ecology Letters 12, 930-941. https://doi.org/10.1111/j.14610248.2009.01352.x.

Métailié, J.P. 1981. Le feu pastorale dans les Pyrénées centrales. CNRS Editions, Toulouse.

Métailié, J.P. 2006. Mountain landscape, pastoral management and traditional practices in the Northern Pyrenees (France). In: M. Agnoletti (Ed.), The conservation of cultural landscapes. CAB Int, Cambridge, pp. 108-123.

Montserrat, P. 1978. El incendio de pastizales y sus peligros. Pastos 8 (1), 31-36.

Montserrat, P. 1988. Ecología y culturas del ambiente vasco. Actas del Congreso de Biología Ambiental Vol I, pp. 19-31. Universidad del País Vasco y Gobierno Vasco.

Villar, L., Montserrat, P. 1996. El pastoreo que modela los paisajes de montaña. Actas de la XXXVI Reunión Científica de la SEEP. Logroño, pp 121-124.

Nadal Romero,E., Lasanta, T., Cerdá, A. 2018. Integrating extensive livestock and soil conservation policies in mediterranean mountain areas for recovery of abandoned lands in the Central Spanish Pyrenees. A long-term research assessment. Land Degradation. Development 29, 262-273. https://doi.org/10.1002/ldr.2542.

Osoro, K., Martínez, A., Oliván, M., García, U., Celaya, R. 2005. Manejo de los herbívoros domésticos para la biodiversificación y el desarrollo rural. Actas de la XLV Reunión Científica de la SEEP. Gijón, pp 45-71.

Pinto Correia, T. 1993. Land abandonment: Changes in the land use patterns around the Mediterranean basin. Etat de l'Agriculture en Méditerranée. Les sols dans la région méditerranéenne : utilisation, gestion et perspectives d'évolution. Cahiers Options Méditerranéennes 1 (2), 97-112.

Redhead, J., Cuevas-Gónzales, M., Smith, G., Gerard, F., Pywell, R. 2012. Assessing the effectiveness of scrub management at the landscape scale using rapid field assessment and remote sensing. Journal of Environmental Management 97, 102-108. https://doi. org/10.1016/j.jenvman.2011.12.005.

Remón Aldabe, J.L. 2008. Plan de Ordenación de Pastos de Aralar. Informe técnico. Gobierno de Navarra. 
Reyes, O., Casal, M. 2008. Regeneration models and plant regenerative types related to the intensity of fire in Atlantic shrubland and woodland species. Journal of Vegetation Science 19, 575-583. https://doi.org/10.3170/2008-8-18412.

Schlesinger, W.H., Reynolds, J.F., Cunningham, G.L., Huenneke, L.F., Jarrell, W.M., Virginia, R.A., Whitford, W.G. 1990. Biological Feedbacks in Global Desertification. Science 247, 1043-1048. https://doi.org/10.1126/science.247.4946.1043.

Scholes, R.J., Archer, S.R. 1997. Tree-Grass Interactions in Savannas. Annual Review of Ecology and Systematics 28, 517-544. https://doi.org/10.1146/annurev.ecolsys .28.1.517.

Van Auken, O.W. 2000. Shrub Invasions of North American Semiarid Grasslands. Annual Review of Ecology and Systematics 31, 197-215. https://doi.org/10.1146/annurev.ecolsys.31.1.197.

Van Vegten, J.A. 1984. Thornbush Invasion in a Savanna Ecosystem in Eastern Botswana. Vegetatio 56, 3-7. https://doi.org/10.1007/BF00036129.

Verdú, M. 2000. Ecological and evolutionary differences between mediterranean seeders and resprouters. Journal of Vegetation Science 11, 265-268. https://doi.org/10.2307/3236806.

Ward, L.K., 1990. Management of grassland-scrub mosaics. In: S.H. Hillier, D.W.H. Wilton, D.A. Wells (Eds.), Calcareous Grassland: Ecology and Management. Bluntisham Books, Bluntisham, pp. 134-139.

Zarovali, M.P., Yiakoulaki, M.D., Papanastasis, V.P. 2007. Effects of shrub encroachment on herbage production and nutritive value in semi-arid Mediterranean grasslands. Grass and Forage Science 62, 355-363. https://doi.org/10.1111/j.1365-2494.2007.00590.x. 